\title{
Impact of Plant Growth Promoting Bacteria on Salicornia ramosissima Ecophysiology and Heavy Metal Phytoremediation Capacity in Estuarine Soils
}

\section{OPEN ACCESS}

Edited by:

Eric Altermann,

AgResearch Ltd., New Zealand

Reviewed by:

Santosh Kr Karn,

Sardar Bhagwan Singh Post

Graduate Institute of Biomedical

Sciences \& Research, India

Naresh Singhal,

The University of Auckland,

New Zealand

*Correspondence:

Jennifer Mesa-Marín

jmesam@uma.es;

jmesam@us.es

Specialty section:

This article was submitted to

Microbiotechnology,

a section of the journal

Frontiers in Microbiology

Received: 17 April 2020

Accepted: 13 August 2020

Published: 17 September 2020

Citation:

Mesa-Marín J, Pérez-Romero JA,

Redondo-Gómez S, Pajuelo E,

Rodríguez-Llorente ID and

Mateos-Naranjo E (2020) Impact of Plant Growth Promoting Bacteria

on Salicornia ramosissima

Ecophysiology and Heavy Metal

Phytoremediation Capacity

in Estuarine Soils.

Front. Microbiol. 11:553018.

doi: 10.3389/fmicb.2020.553018

\section{Jennifer Mesa-Marín ${ }^{*}$, Jesús A. Pérez-Romero², Susana Redondo-Gómez²,} Eloísa Pajuelo ${ }^{3}$, Ignacio D. Rodríguez-Llorente ${ }^{3}$ and Enrique Mateos-Naranjo ${ }^{2}$

\footnotetext{
' Departamento de Biología Molecular y Bioquímica, Facultad de Ciencias, Universidad de Málaga, Málaga, Spain, ${ }^{2}$ Departamento de Biología Vegetal y Ecología, Facultad de Biología, Universidad de Sevilla, Seville, Spain, ${ }^{3}$ Departamento de Microbiología y Parasitología, Facultad de Farmacia, Universidad de Sevilla, Seville, Spain
}

Salicornia ramosissima is a $\mathrm{C}_{3}$ halophyte that grows naturally in South Western Spain salt marshes, under soil salinity and heavy metal pollution (mostly $\mathrm{Cu}, \mathrm{Zn}$, As, and $\mathrm{Pb}$ ) caused by both natural and anthropogenic pressure. However, very few works have reported the phytoremediation potential of $S$. ramosissima. In this work, we studied a microbe-assisted phytoremediation strategy under greenhouse conditions. We inoculated plant growth promoting (PGP) and heavy metal resistant bacteria in pots with $S$. ramosissima and natural non-polluted and polluted sediments collected from Spanish estuaries. Then, we analyzed plant ecophysiological and metal phytoaccumulation response. Our data suggested that inoculation in polluted sediments improved S. ramosissima plant growth in terms of relative growth rate (RGR) (32\%) and number of new branches (61\%). S. ramosissima photosynthetic fitness was affected by heavy metal presence in soil, but bacteria inoculation improved the photochemical apparatus integrity and functionality, as reflected by increments in net photosynthetic rate $(21 \%)$, functionality of PSII $\left(F_{m}\right.$ and $\left.F_{v} / F_{m}\right)$ and electron transport rate, according to OJIP derived parameters. Beneficial effect of bacteria in polluted sediments was also observed by augmentation of intrinsic water use efficiency (28\%) and slightly water content (2\%) in inoculated S. ramosissima. Finally, our results demonstrated that S. ramosissima was able to accumulate great concentrations of heavy metals, mostly at root level, up to $200 \mathrm{mg} \mathrm{Kg}^{-1}$ arsenic, $0.50 \mathrm{mg} \mathrm{Kg}^{-1}$ cadmium, $400 \mathrm{mg} \mathrm{Kg}^{-1}$ copper, $25 \mathrm{mg} \mathrm{Kg}^{-1}$ nickel, $300 \mathrm{mg} \mathrm{Kg}^{-1}$ lead, and $300 \mathrm{mg} \mathrm{Kg}^{-1}$ zinc. Bioaugmentation incremented $S$. ramosissima heavy metal phytoremediation potential due to plant biomass increment, which enabled a greater accumulation capacity. Thus, our results suggest the potential use of heavy metal resistant PGPB to ameliorate the capacity of S. ramosissima as candidate for phytoremediation of salty polluted ecosystems. 


\section{INTRODUCTION}

Environmental pollution has become a major public concern over the last century. Specially, heavy metal content in water and soil has increased due to rapid worldwide industrial development (Usman et al., 2018). This problem is further compounded by soils simultaneously affected by salinity because of climate change and irrigated agriculture (Liang et al., 2017). To overcome this, phytoremediation has been largely studied and suggested as an environmentally friendly and low-cost clean-up method. However, a great proportion of the known phytoremediators are glycophytes, and they cannot survive the combination of salt and heavy metal pollution long enough to be effective (Wang et al., 2014). Conversely, halophytes are able to survive in saline environments (Flowers and Colmer, 2008) and are naturally adapted to tolerate metals, compared to glycophytes (Van Oosten and Maggio, 2015; Liang et al., 2017). Thus, halophytes may represent excellent candidates for phytoremediation of heavy metals in soils with high salinity (Anjum et al., 2014), as have been demonstrated by several species from the genera Atriplex, Tamarix, Sporobolus, Juncus, Suaeda, etc. (Manousaki and Kalogerakis, 2011; Redondo-Gómez, 2013). Among processes that halophytes use for phytoremediation are: (i) phytoextraction (plants take metals from the soil and transport and concentrate them in harvestable above-ground tissues), (ii) phytovolatilization (plants take water soluble metals and release them as they transpire the water), (iii) phytostabilization (plants completely immobilize the metals through accumulation by roots or precipitation within the rhizosphere), (iv) rhizofiltration (plants absorb, concentrate and precipitate pollutants of water), (v) phytoaccumulation (pollutants are accumulated in plants' biomass), and (vi) phytodegradation (pollutants are degraded into insoluble or non-toxic compounds) (Anjum et al., 2014). Phytoremediation strategy is based on major plants, but also on associated microbes and their processes. In this sense, plant growth promoting bacteria (PGPB) bioaugmentation has been proposed as a strategy to improve innate heavy metal phytoremediation capacity in halophytes, since it has been proven to ameliorate plant growth, stress tolerance and phytoremediation potential (Backer et al., 2018). Indeed, positive results have been recently obtained for Spartina, Arthrocnemum, and Suaeda species, which incremented their root metal phytoaccumulation capacity when they were PGPB-treated (Mateos-Naranjo et al., 2015; Mesa et al., 2015b; Navarro-Torre et al., 2017a; Gómez-Garrido et al., 2018).

An ideal case of study in this matter can be found in Odiel salt marsh (SW Spain). In this area, halophytes grow in soils containing salt and heavy metals. Recent studies in Odiel soils registered around $200 \mathrm{mM} \mathrm{NaCl}$ and approximately $150 \mathrm{mg}$ $\mathrm{Kg}^{-1} \mathrm{As}, 3 \mathrm{mg} \mathrm{Kg}{ }^{-1} \mathrm{Cd}, 5 \mathrm{mg} \mathrm{Kg}{ }^{-1} \mathrm{Co}, 900 \mathrm{mg} \mathrm{Kg}^{-1} \mathrm{Cu}$, $30 \mathrm{mg} \mathrm{Kg}^{-1} \mathrm{Ni}, 300 \mathrm{mg} \mathrm{Kg}{ }^{-1} \mathrm{~Pb}$, and $1700 \mathrm{mg} \mathrm{Kg}^{-1} \mathrm{Zn}$ (Mesa et al., 2016). Pollution levels in the estuary are caused by both natural and anthropogenic pressure (Mesa et al., 2016). Salicornia ramosissima $\mathrm{J}$. Woods is a $\mathrm{C}_{3}$ halophyte that grows naturally in Odiel estuary area. It is a widespread plant on the European coastline, including salt marshes of the Iberian Peninsula, where it usually occupies the higher reaches of the salt marsh and is a pioneer species in the colonization of the intertidal zones of such habitats (Davy et al., 2001). These features, together with the potential for metal bioremediation of the genus Salicornia observed by some authors (Ozawa et al., 2010; Sharma et al., 2010; Kaviani et al., 2017a,b; Lou et al., 2020), make S. ramosissima an excellent candidate for land restoration. For example, root exudates from Salicornia europaea could form $\mathrm{Pb}$-complexes which help $\mathrm{Pb}$-stabilization and, therefore, remediation (Pan et al., 2012). Also, Shrestha et al. (2006) reported in Salicornia bigelovii 2.2-fold more biogenic volatile Se compared to the control. However, the metal accumulation ability of the species $S$. ramosissima has been scarcely studied. Only a few works reported S. ramosissima phytoaccumulation abilities. Pedro et al. (2013) concluded that this species may be useful for phytoaccumulation and phytostabilization, since plants have a considerable bioaccumulation potential and were able to bioaccumulate $\mathrm{Cd}$ mainly in the roots, acting like a sink for this metal and preventing it from becoming available to other organisms. Pérez-Romero et al. (2016) confirmed the traits of Cd accumulation and tolerance of S. ramosissima, and stated that this tolerance could be due to many of essential steps of its photosynthetic pathway were tolerant to Cd excess. On the other hand, PGPB treatments have been never tested on S. ramosissima with phytoremediation purposes. In a previous work, we isolated PGPB from the rhizosphere of S. ramosissima growing in SW Spain salt marshes and designed a bacterial consortium for inoculation (Mesa-Marín et al., 2019c). We hypothesize that S. ramosissima may accumulate heavy metals in its tissues when it grows in a polluted soil, and that bioaugmentation treatment with the bacterial inoculum mentioned above may improve growth of $S$. ramosissima and its metal accumulation capacity. Thus, this is the first work that studies the phytoremediation capacity of PGPB-treated S. ramosissima.

Then, this work aimed at (1) assessing the tolerance to heavy metals of the bacteria selected for inoculation, in order to ensure they can be used in polluted sediments, (2) describing heavy metal accumulation capacity of $S$. ramosissima growing in natural salt marsh sediments, and (3) analyzing S. ramosissima response to PGPB inoculation in terms of growth, photosynthetic fitness, and metal accumulation.

\section{MATERIALS AND METHODS}

\section{Plant and Soil Source}

Seeds of S. ramosissima were collected in December 2017 from Odiel $\left(37^{\circ} 15^{\prime} \mathrm{N}, 6^{\circ} 58^{\prime} \mathrm{W}\right.$; SW Spain) and Piedras $\left(37^{\circ} 16^{\prime} 09.1^{\prime \prime} \mathrm{N}\right.$ $7^{\circ} 09^{\prime} 36.4^{\prime \prime} \mathrm{W}$; SW Spain) marshes. Later, they were kept in darkness at $4^{\circ} \mathrm{C}$ up to 3 months. Prior to the experiment, seeds were surface-disinfected and germinated as indicated in MateosNaranjo et al. (2015). Seedlings were planted in perlite (in $11 \mathrm{~cm}$ diameter $\times 9 \mathrm{~cm}$ high pots), in a glasshouse with $40-60 \%$ relative humidity, natural daylight and $21-25^{\circ} \mathrm{C} .20 \%$ Hoagland's solution (Hoagland and Arnon, 1938) was used to irrigate pots as necessary. For our experiment, two natural marshy soils were used. Soil from the Piedras estuary (Huelva, SW Spain), with no anthropogenic influence and thereby non-polluted, was 
used to grow S. ramosissima control plants, and soil from the Odiel estuary (Huelva, SW Spain) was used to grow plants under polluted conditions. Metal concentration of both soils is available in Table 1. Arsenic, copper and lead concentrations were especially high in Odiel salt marshes (ca. 800, 1000, and $1100 \mathrm{mg} \mathrm{Kg}^{-1}$, respectively), constituting $60 \times, 30 \times$, and $35 \times$ times, respectively, compared to Piedras sediments.

\section{Bacterial Tolerance Against Heavy Metals}

Bacteria used as an inoculum in this experiment were isolated from $S$. ramosissima rhizosphere, growing in the Tinto salt marsh (SW Spain, 37 $13^{\prime} 51.40^{\prime \prime} \mathrm{N} 6^{\circ} 54^{\prime} 28.40^{\prime \prime} \mathrm{W}$ ) (Mesa-Marín et al., 2019c). They were identified as Vibrio neocaledonicus SRT1, Thalassospira australica SRT8 and Pseudarthrobacter oxydans SRT15, and they were selected among other rhizosphere isolates based on their outstanding Plant Growth Promoting (PGP) properties (Mesa-Marín et al., 2019c). This bacterial consortium showed nitrogen fixation abilities, phosphate solubilization and biofilm-forming capacity, as well as production of 1aminocyclopropane-1-carboxylate (ACC) deaminase, indole-3acetic acid (IAA), and siderophores (Table 2; Mesa-Marín et al., 2019c). For this work, heavy metal tolerance of these bacteria was analyzed. Single strains were streaked on TSA $0.2 \mathrm{M}$ $\mathrm{NaCl}$ medium (in line with salt marshes soil conductivity) and supplemented with increasing concentrations of heavy metals and metalloids from stock solutions: $\mathrm{NaAsO}_{2} 0.5 \mathrm{M}, \mathrm{CdCl}_{2} 1$ $\mathrm{M}, \mathrm{CuSO}_{4} 1 \mathrm{M}, \mathrm{CoCl}_{2} 1 \mathrm{M}, \mathrm{NiCl}_{2} 0.2 \mathrm{M}, \mathrm{ZnSO}_{4} 1 \mathrm{M}$, and $\mathrm{Pb}\left(\mathrm{NO}_{3}\right)_{2}$ 0.5 $\mathrm{M}$ (in order to avoid $\mathrm{Pb}$ precipitation when mixing with TSA, the same concentration of EDTA needs to be added to the plates). Tolerance was assessed for each strain and heavy metal separately. After incubation at $28^{\circ} \mathrm{C}$ during $72 \mathrm{~h}$, maximum tolerable concentration (MTC) was expressed for each strain and element, namely the maximum concentration of a metal or metalloid that permitted bacterial growth in plates.

\section{Experimental Treatments}

Pots containing Piedras and Odiel sediment were planted with S. ramosissima and assigned randomly to two bacterial bioaugmentation treatments: non-inoculated (control) and inoculated with the selected PGPB $(n=40,2$ soils $\times 2$ bacterial treatments $=4$ treatments, 10 pots per treatment). Pots were put in trays with tap water down to a depth of $1 \mathrm{~cm}$. During the experimental period, 30 days, water level in the trays were checked every 2 days. Inoculated pots were watered with $50 \mathrm{ml}$ of a bacterial suspension at the beginning of the experiment, while control pots were watered with $50 \mathrm{ml}$ of tap water. Inoculant suspensions were prepared as described in Mesa-Marín et al. (2019c). Finally, bacteria pellets were resuspended in tap water until it was obtained a suspension with $\mathrm{OD}_{600}=1$ (approx. $10^{8}$ cells per $\mathrm{ml}$ ) for each strain. Equal amounts of each strain were mixed to obtain the final $\mathrm{OD}_{600}=1$ inoculant suspension. The final volume of inoculant suspension was $1 \mathrm{~L}$, to water 20 pots with $50 \mathrm{ml}$ each.

\section{Salicornia ramosissima Growth and Water Status Analysis}

Six S. ramosissima plants were harvested before the initiation of the experiment and the rest were collected after 30 days of bioaugmentation treatment. The relative growth rate (RGR) of S. ramosissima was calculated (Mesa et al., 2015b). Also, all $S$. ramosissima height and number of ramifications were recorded at the beginning and the end of the experimental period. Furthermore, water content (WC) of primary branches ( $n=9$ per each soil and bacterial treatment combination) were calculated as follow:

$$
\mathrm{WC}=[(\mathrm{FW}-\mathrm{DW}) / \mathrm{FW}] \times 100
$$

where FW = fresh weight of the branches and DW = dry weight after oven-drying at $80^{\circ} \mathrm{C}$ for $48 \mathrm{~h}$.

\section{Salicornia ramosissima Photosynthetic Performance Analysis}

One day before plants were harvested, gas exchange parameters were measured on primary branches $(n=10$, per each soil and bacterial treatment combination) using an infrared gas analyzer (LI-6400, LI-COR Inc., Neb., United States) in an open system. It was equipped with a light leaf chamber (Li-6400-02B, Li-Cor Inc.). Thus, stomatal conductance $\left(\mathrm{g}_{s}\right)$, intercellular

TABLE 1 | Metal(loid) concentrations in $\mathrm{mg} \mathrm{Kg}^{-1}$ in sediments from Odiel to Piedras salt marshes used in this study.

\begin{tabular}{|c|c|c|c|c|c|c|}
\hline Location & As & Cd & $\mathrm{Cu}$ & $\mathrm{Ni}$ & $\mathrm{Pb}$ & $\mathrm{Zn}$ \\
\hline Piedras & $14.22 \pm 0.41$ & $0.20 \pm 0.12$ & $37.35 \pm 1.43$ & $24.28 \pm 0.47$ & $31.95 \pm 0.16$ & $108.57 \pm 3.75$ \\
\hline Odiel & $853.54 \pm 34.45$ & $2.19 \pm 0.7$ & $1076.39 \pm 58.55$ & $28.77 \pm 1.48$ & $1139.85 \pm 58.76$ & $809.92 \pm 40.06$ \\
\hline
\end{tabular}

Values are means \pm S.E.

TABLE 2 | Plant growth promoting traits for bacterial consortia used in this study (Mesa-Marín et al., 2019c).

\begin{tabular}{|c|c|c|c|c|c|c|}
\hline Strain & Nitrogen fixation ${ }^{a}$ & $\begin{array}{c}\text { Phosphate } \\
\text { solubilization }^{b}\end{array}$ & $\begin{array}{l}\text { Siderophores } \\
\text { production }^{b}\end{array}$ & $\begin{array}{l}\text { IAA production } \\
(\mathrm{mg} / \mathrm{mL})\end{array}$ & $\begin{array}{l}\text { Biofilm } \\
\text { production }^{a}\end{array}$ & $\begin{array}{l}\text { ACC deaminase activity ( } \mu \\
\text { mol } \alpha \text {-cetog } \mathrm{h}^{-1} \mathrm{mg} \mathrm{prot}^{-1} \text { ) }\end{array}$ \\
\hline SRT1 & + & 10 & 20 & 5.65 & + & - \\
\hline SRT8 & - & - & - & - & +- & 1.24 \\
\hline SRT15 & + & 9 & - & 20.99 & + & - \\
\hline
\end{tabular}

a (+) presence or (-) absence of growth; ${ }^{b}$ halo diameter in $\mathrm{mm}$. 
$\mathrm{CO}_{2}$ concentration $\left(\mathrm{C}_{i}\right)$, net photosynthetic rate $\left(\mathrm{A}_{N}\right)$, and instantaneous water use efficiency ( ${ }_{i}$ WUE; ratio between $A_{N}$ and $\mathrm{g}_{s}$ ) were obtained with the following leaf chamber settings: photon flux density (PPFD) of $1000 \mu \mathrm{mol}$ photons $\mathrm{m}^{-2} \mathrm{~s}^{-1}$ (with $15 \%$ blue light to maximize stomatal aperture), $\mathrm{CO}_{2}$ concentration $\left(C_{a}\right)$ surrounding leaf of $400 \mu \mathrm{mol} \mathrm{mol}^{-1}$ air, air temperature of $24 \pm 1^{\circ} \mathrm{C}$, relative humidity of $45 \pm 5 \%$, and vapor pressure deficit of $2.0-3.0 \mathrm{kPa}$.

Furthermore, chlorophyll fluorescence measurements were performed in the same branches of gas exchange analysis using a FluorPen FP100 (Photo System Instruments, Czechia). Thus, the chlorophyll $a$ fast kinetics, or JIP-test (or Kautsky curves), which depicts the rate of reduction kinetics of various components of PSII, were measured in 30 min dark-adapted branches $(n=6$, per each soil and bacterial treatment combination), using the pre-programmed OJIP test implemented in the pre-programmed protocols of the FluorPen. Maximum quantum efficiency of PSII photochemistry $\left(\mathrm{F}_{v} / \mathrm{F}_{m}\right)$, absorbed energy flux (ABS/CS), trapped energy flux (TR/CS), electron transport energy flux (ET/CS), and dissipated energy flux (DI/CS) per reaction center derived for OJIP were calculated (Strasser et al., 2004).

\section{Chemical Analyses of Salicornia ramosissima Tissues}

Salicornia ramosissima roots and leaves were carefully washed with distilled water at the end of the experiment to eliminate ions from their surface before the analysis. At the end of the experiment, dried roots and leaves were ground (Mateos-Naranjo et al., 2008). $0.5 \mathrm{~g}$ sub-samples were taken from the roots and the leaves of the ten replicate plants. Phosphorus $(\mathrm{P})$, sodium $(\mathrm{Na})$, magnesium $(\mathrm{Mg})$, manganese $(\mathrm{Mn})$, calcium $(\mathrm{Ca})$, potassium $(\mathrm{K})$, arsenic (As), cadmium $(\mathrm{Cd})$, copper $(\mathrm{Cu})$, nickel $(\mathrm{Ni})$, lead $(\mathrm{Pb})$, and zinc $(\mathrm{Zn})$ were measured by inductively coupled plasma (ICP) spectroscopy (ARL-Fison 3410, United States) in tissues and soil.

\section{Statistical Analysis}

Statistics were analyzed with "Statistica" v. 10.0 (StatSoft Inc.). Generalized linear models (GLM) aided to analyze the interactive effects of soil pollution and bacterial treatments (as categorical factors) on the growth, chlorophyll fluorescence and gas exchange of $S$. ramosissima plants (as dependent variables), followed by a LSD (post hoc) test for multiple comparisons analysis. Nutrient and heavy metal content in $S$. ramosissima leaves and roots after different bioaugmentation treatments were compared by the Student test ( $T$-test), and values were analyzed for each tissue by using one-way ANOVA (F-test). Data normality was tested with the Kolmogorov-Smirnov test and data homogeneity of variance with the Brown-Forsythe test. Tukey (post hoc) tests were used for identification of important contrasts. In all cases, a significance level of $p<0.05$ was used.

\section{RESULTS}

\section{Rhizobacteria Tolerance to Heavy Metals}

Bacteria selected in this work for bioaugmentation treatments were Vibrio neocaledonicus SRT1, Thalassospira australica SRT8, and Pseudarthrobacter oxydans SRT15. They were isolated from $S$. ramosissima rhizosphere growing in heavy metal polluted Tinto salt marsh (SW Spain). Isolation was conducted by pourplating a mix of rhizospheric soil and physiological saline solution $(\mathrm{NaCl} 0.9 \% \mathrm{w} / \mathrm{v})$ on tryptic soy agar (TSA) $\mathrm{NaCl} 0.2 \mathrm{M}$ and further streaking of single colonies in the same medium, with incubations at $28^{\circ} \mathrm{C}$ for 24-48 h (Mesa-Marín et al., 2019c). SRT1 exhibited nitrogen fixation and phosphate solubilization, as well as the capacity to produce siderophores and biofilms. SRT8 produced ACC deaminase and SRT15 showed the best auxins production (Table 2). In this work, heavy metal tolerance of these strains was tested (Table 3). Strain SRT1 showed the broadest tolerance, with particular emphasis on As, Cd, and Co. Overall, the three strains showed a notable tolerance to $\mathrm{Zn}$ (ranging from 1 to $3 \mathrm{mM}$ ), $\mathrm{Pb}$ (from 3 to $5 \mathrm{mM}$ ), $\mathrm{Ni}$ (up to $9 \mathrm{mM}$ ), $\mathrm{Cu}$ (up to $3 \mathrm{mM}$ ), and Co (from 3 to $13 \mathrm{mM}$ ).

\section{Soil Bioaugmentation Effect on Salicornia ramosissima Growth and Water Content}

After 30 days of treatment bacterial inoculation improved S. ramosissima RGR compared to non-inoculated plants (Figure 1A). Soil bioaugmentation incremented RGR $45 \%$ in non-polluted Piedras sediments and $32 \%$ in polluted Odiel sediments ( $\left.\mathrm{GLM}_{\text {inoc }}, p<0.05\right)$. Also, at the end of the treatment, inoculated $S$. ramosissima showed significant increments of stem branches compared to control (Figure 1B), 32\% in nonpolluted sediments and $61 \%$ in polluted sediments $\left(\mathrm{GLM}_{\text {soilxinoc }}\right.$, $p<0.05$ ). However, for S. ramosissima stem height there was no statistically significant difference in any case (data not shown). Plant water content (Figure 1C) did not vary with inoculation in non-polluted sediments. Conversely, it was higher in inoculated plants grown in polluted sediments $\left(\mathrm{GLM}_{\text {soil,inoc }} p<0.05\right)$.

\section{Soil Bioaugmentation Effect on Salicornia ramosissima Photosynthetic Apparatus Performance}

As shown in Figure 2, S. ramosissima growing in polluted sediments had higher ${ }_{i} \mathrm{WUE}$, and lower $\mathrm{A}_{N}, \mathrm{~g}_{s}$, and $\mathrm{C}_{i}$,

TABLE 3 | Maximum tolerable concentration (MTC) in mmoles $\mathrm{L}^{-1}$ (mM) for each rhizobacteria strain and metal(loid) tested.

\begin{tabular}{|c|c|c|c|c|c|c|c|}
\hline Strain & As $\left(\mathrm{NaAsO}_{2}\right)$ & $\mathrm{Cd}\left(\mathrm{CdCl}_{2}\right)$ & Co $\left(\mathrm{CoCl}_{2}\right)$ & $\mathrm{Cu}\left(\mathrm{CuSO}_{4}\right)$ & $\mathrm{Ni}\left(\mathrm{NiCl}_{2}\right)$ & $\mathrm{Pb}\left(\mathrm{Pb}\left(\mathrm{NO}_{3}\right)_{2}\right)$ & $\mathrm{Zn}\left(\mathrm{ZnSO}_{4}\right)$ \\
\hline SRT1 & 5 & 4 & 13 & 3 & 9 & 5 & 3 \\
\hline SRT8 & $<1$ & 0.3 & 3 & 3 & 1 & 5 & 1 \\
\hline SRT15 & $<1$ & $<0.1$ & 5 & 1 & 9 & 3 & 1 \\
\hline
\end{tabular}




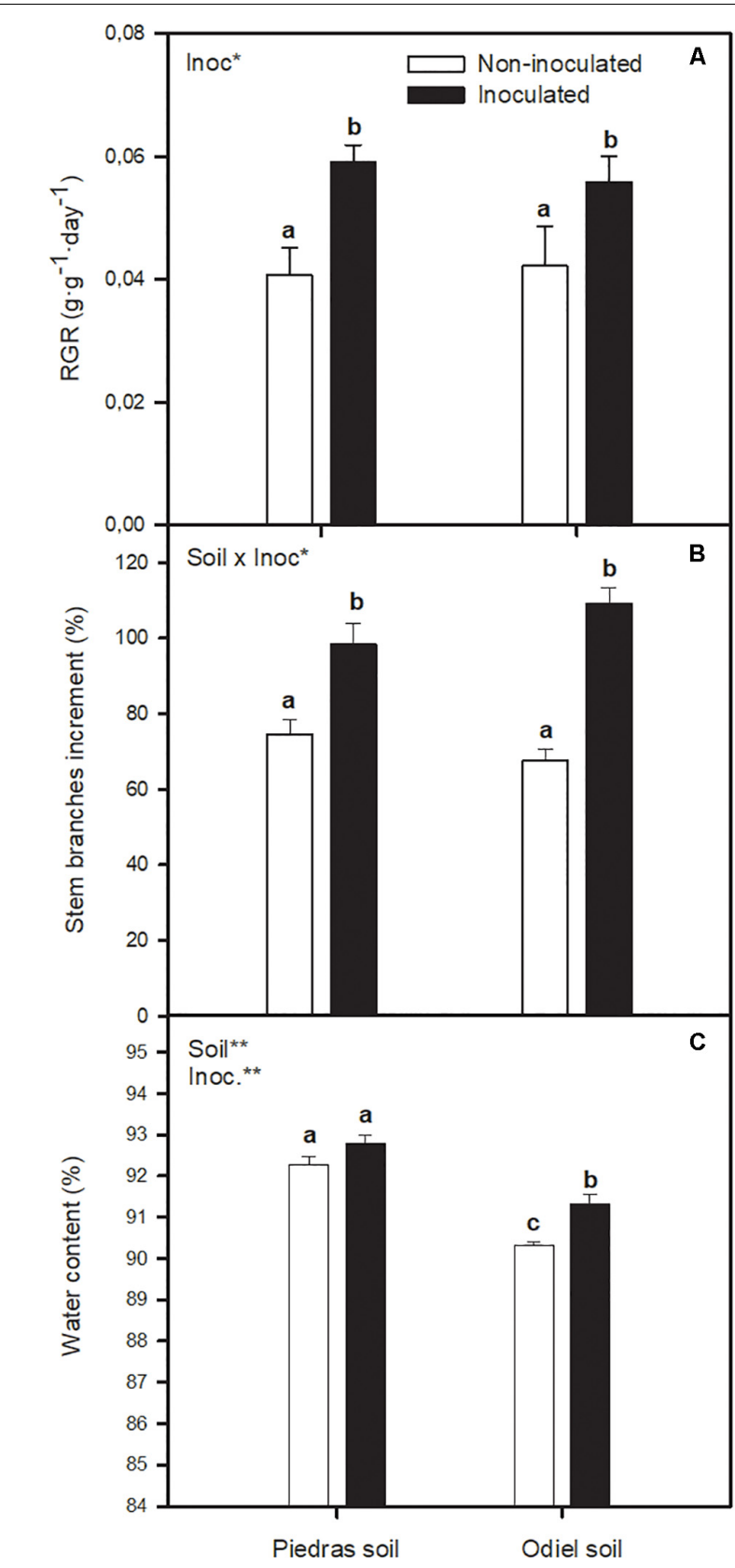

FIGURE 1 | Effect of soil bioaugmentation treatments (non-inoculated and inoculated) with a bacterial consortium integrated by Vibrio neocaledonicus SRT1, Thalassospira australica SRT8 and Pseudarthrobacter oxydans SRT15 on $\mathbf{( A )}$ relative growth rate, $R G R$, (B) number of stem branches and $(\mathbf{C})$ water content of Salicornia ramosissima plants grown in natural soil from non-polluted Piedras and polluted Odiel marshes for 30 days. Values are means \pm S.E. $(n=10)$. "Inoc" or "Soil" in the upper left corner of the panel indicates main or interaction significant effect $\left({ }^{*} p<0.1,{ }^{* *} p<0.01\right)$. Different letters indicate means that are significantly different from each other $(p<0.05)$.

compared to plants growing in non-polluted sediments ( $T$-test, $p<0.05)$. Soil bioaugmentation with rhizobia did not altered S. ramosissima $\mathrm{A}_{N}, \mathrm{~g}_{s}, \mathrm{C}_{i}$, and ${ }_{i} \mathrm{WUE}$ in non-polluted soil
(Figures 2A-D). Conversely, soil bioaugmentation in polluted sediments significantly incremented $\mathrm{A}_{N}$ and ${ }_{i}$ WUE, while lowered $\mathrm{C}_{i}$ (GLM soil,inoc,soil $\times$ inoc $p<0.05$; Figures 2AD). Figure 3 illustrates changes in chlorophyll fluorescence parameters after 30 days of treatments. In this case, $F_{m}$ and $\mathrm{F}_{v} / \mathrm{F}_{m}$ showed a clear pattern of statistically significant variation in both sediments and inoculation treatments. Both parameters decreased for inoculated plants in non-polluted soil, while they increased after inoculation in polluted soils (GLM soil,soil $\times$ inoc, $p>0.05$; Figures 3A,B). Finally, focusing on OJIP derived parameters (Figure 4), we found that bioaugmentation treatments and soil pollution degree did not affect ABS/CS and ET/CS values (GLM, $p>0.05$; Figures 4A,B), while TR/C values decreased in polluted soil in similar degree at both inoculation treatments $\left(\mathrm{GLM}_{\text {soil }}, p<0.05\right.$; Figure 4C). Contrarily, there was an increment in DI/RC values under metal pollution conditions but this augmentation was more accused in non-inoculated plants $\left(\mathrm{GLM}_{\text {soil } \times \text { inoc }}, p>0.05\right.$; Figure 4D).

\section{Soil Bioaugmentation Effect on Salicornia ramosissima Tissues Nutrient Profile}

At the end of the experiment, rhizobacterial consortium addition altered nutrient profile in a greater extent in leaves than in roots of $S$. ramosissima (two-way Anova, $p<0.01$; Table 4). Soil bioaugmentation in non-polluted sediments produced greater concentrations of $\mathrm{Ca}, \mathrm{Mg}, \mathrm{Mn}$, and $\mathrm{Na}$ in $S$. ramosissima leaves than their non-inoculated counterparts. Conversely, soil bioaugmentation in polluted soil only increased $\mathrm{Na}$ concentrations in leaves (two-way Anova, $p<0.01$; Table 4). It is noteworthy that rhizobacterial treatment increased in both cases Na uptake in leaves $16 \%$.

\section{Salicornia ramosissima Heavy Metal Accumulation Capacity and Effect of Soil Bioaugmentation}

Salicornia ramosissima growing in polluted sediments accumulated great concentrations of heavy metals in its tissues, compared to plants growing in non-polluted sediments (Tables 4, 5). This natural bioaccumulation capacity was particularly noticeable in $S$. ramosissima roots, reaching concentrations of 31,14 or 17 times more $\mathrm{As}, \mathrm{Cu}$, and $\mathrm{Pb}$, respectively, than plants growing in non-polluted sediments ( $T$-test, $p<0.01$; Table 6). Ni concentration was similar in both cases, as Ni concentration in both soils was the same (Table 1).

Bioaugmentation effect on S. ramosissima metal accumulation capacity was studied in polluted sediments (Figure 5). Concentration of ions was higher in roots than in S. ramosissima leaves ( $T$-test, $p<0.01$; Figures $5 \mathbf{A}-\mathbf{L}$ ). Our data revealed that there was no statistical difference in metal concentration per $\mathrm{Kg}$ of $\mathrm{S}$. ramosissima roots or leaves between inoculation conditions after 30 days of experiment (one-way ANOVA, $p>0.05$; Figures 5A-F). However, when $S$. ramosissima biomass gaining was taken into account for each treatment at the end of the experiment, results varied. This is, S. ramosissima plants inoculated with the rhizobacterial consortium, which 


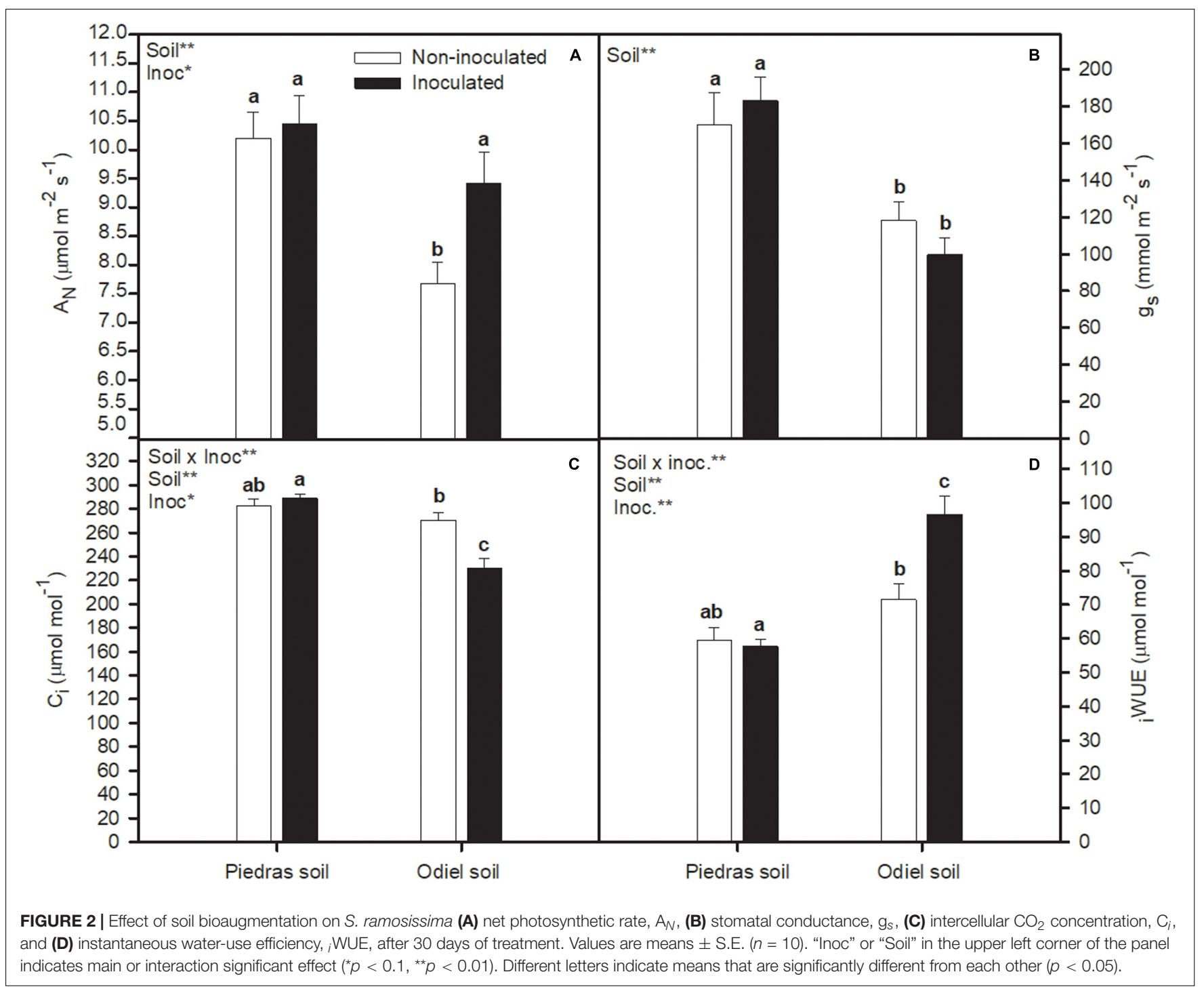

showed greater growth rates than the non-inoculated ones, showed higher total metal content than the control for all metals assayed, except for Cd (one-way ANOVA, $p<0.05$; Figures 5G-L).

\section{DISCUSSION}

In this work, we used two sediments from SW Spain salt marshes where S. ramosissima grows naturally, with historically well-known different level of heavy metal pollution. Metal concentration in Piedras salt marsh, without anthropogenic influence, remains very similar to that reported in the last decade (Mesa et al., 2016). On the contrary, data obtained in Odiel salt marshes sediments revealed that the concentration of lead and arsenic has increased more than two-fold compared with data compiled in the last decade, while cadmium and zinc concentrations have decreased (Mesa et al., 2016). Spanish Government established threshold values for metal clean-up intervention in soil (de Andalucía, 1999). Concentration of As (ca. $800 \mathrm{mg} \mathrm{Kg}^{-1}$ ), $\mathrm{Cu}$ (ca. $1000 \mathrm{mg} \mathrm{Kg}^{-1}$ ), and $\mathrm{Pb}$ (ca. $1100 \mathrm{mg} \mathrm{Kg}^{-1}$ ) in Odiel sediments surpassed threshold values that Spanish Government stablished as intervention limits, this is, 100,500 , and $1000 \mathrm{mg} \mathrm{Kg}^{-1}$, respectively (de Andalucía, 1999). This fact highlights the importance of looking into efficient eco-friendly restoration strategies in these areas, which have a high ecological value. In this work, we studied a proposal of phytoremediation with PGPB-assisted S. ramosissima. This is in line with our previous studies on PGPB treatments with several Spartina genus in the same area (Mateos-Naranjo et al., 2015; Mesa et al., 2015b).

Data collected in our experiment showed that S. ramosissima responded to bioaugmentation with a bacterial consortium composed by Vibrio neocaledonicus SRT1, Thalassospira australica SRT8, and Pseudarthrobacter oxydans SRT15 (MesaMarín et al., 2019c), as could be seen from diverse physiological parameters. On one hand, PGPB bioaugmentation had in both non-polluted and polluted sediments a positive impact on 


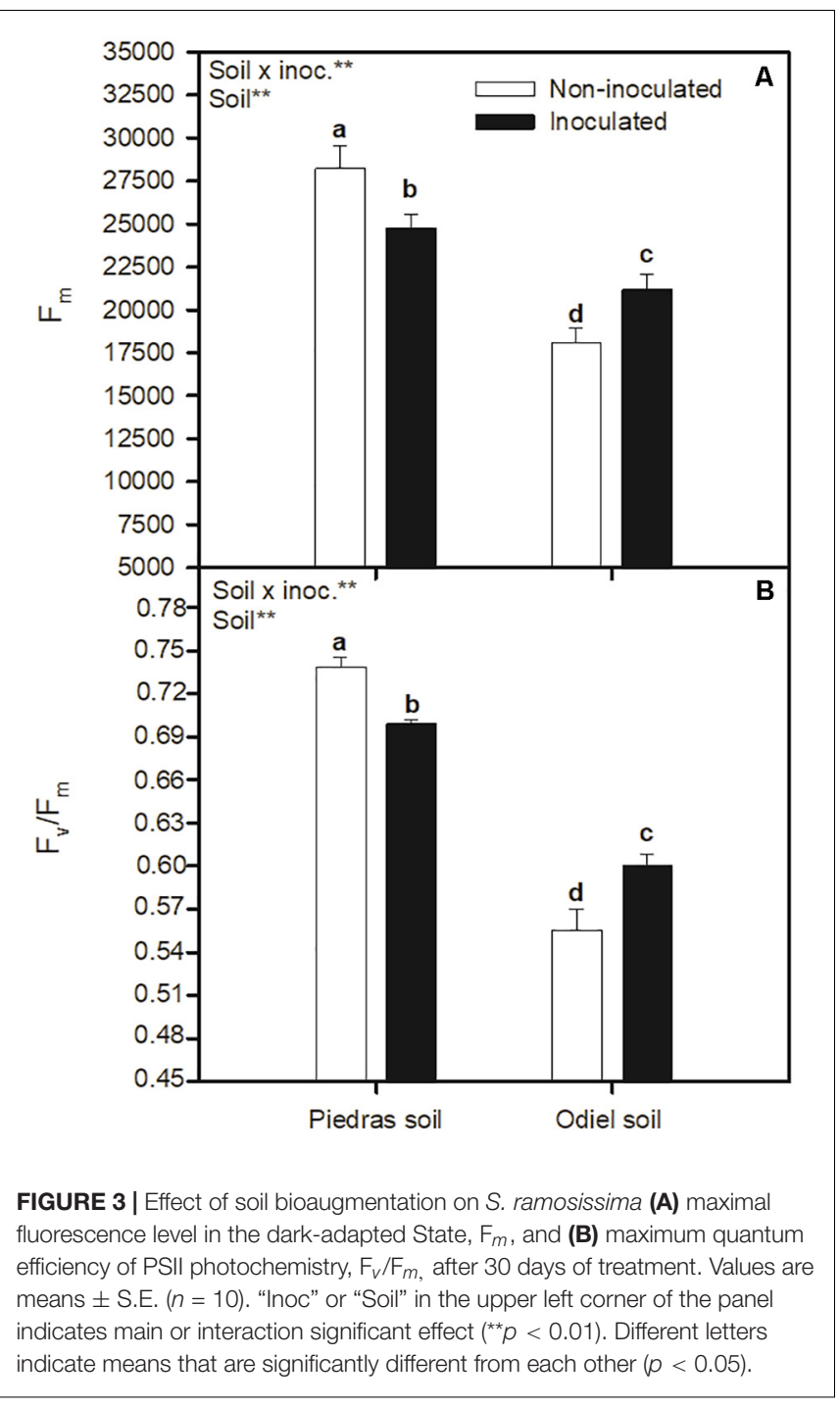

S. ramosissima growth, reflected by RGR results and number of S. ramosissima stem branches. However, height of plants did not vary with bioaugmentation. Increased plant growth may be due to the well-known beneficial properties on plant development and stress tolerance of PGPB (Glick, 2012). In particular, the use of the three PGP strains mentioned above allowed S. ramosissima to benefit from six PGP properties: siderophores, IAA and ACC deaminase production, phosphates solubilization, biofilm formation and nitrogen fixation (MesaMarín et al., 2019c). IAA is a phytohormone with a crucial role in cell differentiation and division, and therefore in root development (Duca et al., 2014). Siderophores sequester and solubilize iron from the soil, facilitating to the plant enough acquisition of this element, especially when there are great amounts of other competing metals (Neilands, 1995). Also, bacterial phosphate solubilizing activity provides plants with a bioavailable form of phosphorus, from immobilized inorganic and organic P compounds that can be found in soil (Glick, 2012). Nitrogen fixing bacteria provide assimilable $\mathrm{N}$ to the plant (de
Souza et al., 2015). Bacteria with the enzyme ACC deaminase degrade the plant ethylene precursor, diminishing ethylene levels in a stressed or developing plant, especially in the presence of salinity excess, and therefore, alleviating plant damage (Glick, 2014; Mesa-Marín et al., 2019b). Finally, there is evidence of the role of biofilms in the presence of heavy metals, by keeping them concentrated, partitioned and immobilized, minimizing the environmental hazards (Bogino et al., 2013). On the whole, Vibrio neocaledonicus SRT1, Thalassospira australica SRT8, and Pseudarthrobacter oxydans SRT15 may improve S. ramosissima nutrient acquisition and stress tolerance to heavy metals, which reflects in an increment in RGR and branch development. In our previous works with Spartina species growing in Piedras, Odiel, and Tinto sediments (SW Spain), Spartina densiflora and Spartina maritima also registered increments in their growth rates after PGPB bioaugmentation, in line with the obtained for S. ramosissima (Mateos-Naranjo et al., 2015; Mesa et al., 2015b).

On the other hand, the positive effect of bacteria inoculation was also supported by improvement in photosynthetic parameters of $S$. ramosissima. Overall, heavy metal pollution clearly affected $S$. ramosissima photosynthetic metabolism, as observed from lower net photosynthetic rate $\left(A_{N}\right)$ values in control plants growing in polluted sediments compared to nonpolluted. In this case, unlike growth, PGPB bioaugmentation had only significant effect in polluted conditions. PGPB inoculation induced a higher plant photosynthetic performance, indicated by greater $\mathrm{A}_{N}$ values. Furthermore, the photosynthetic improvement in inoculated $S$. ramosissima may be related to the greater integrity and functionality of the photochemical apparatus, reflected in terms of functionality of PSII, as indicated by the higher values of $\mathrm{F}_{m}$ and $\mathrm{F}_{v} / \mathrm{F}_{m}$ after 30 days of bioaugmentation. Higher ETR values in inoculated $S$. ramosissima growing in polluted soil demonstrated the maintenance of the functionality of the electron transport chain, reinforcing the positive impact of PGPB inoculation. This fact may ensure enough electrons for carbon fixation through photochemical pathway, which is indeed reflected by $\mathrm{A}_{N}$ values under those suboptimal polluted conditions (Strasser et al., 2004).

Other physiological effects observed in this work were ${ }_{i}$ WUE and water content augmentation in inoculated S. ramosissima in polluted sediments. ${ }_{i}$ WUE is a well-established indicator of plant water managing under conditions of stress (Tardieu, 2012). In a similar manner, greater root growth in S. ramosissima inoculated with bacteria may aid to enhance water absorption capacity and, therefore, water content, iWUE and metal tolerance. In line with these results, previous works from authors of this study reported that bioaugmentation with indigenous PGPB incremented ${ }_{i}$ WUE and other photosynthetic parameters like $A_{N}$ and functionality of PSII in halophytes S. densiflora, S. maritima, and Arthrocnemum macrostachyum (Mateos-Naranjo et al., 2015; Mesa et al., 2015a,b; Navarro-Torre et al., 2017a,b; Paredes-Páliz et al., 2017; MesaMarín et al., 2019a).

Finally, our results revealed that $S$. ramosissima could be considered a heavy metal phytoaccumulator halophyte, as reflected by high concentrations of As (200 mg Kg-1), Cd (0.50 mg Kg ${ }^{-1}$ ), $\mathrm{Cu}\left(400 \mathrm{mg} \mathrm{Kg}{ }^{-1}\right)$, Ni (25 mg Kg$\left.{ }^{-1}\right), \mathrm{Pb}$ 


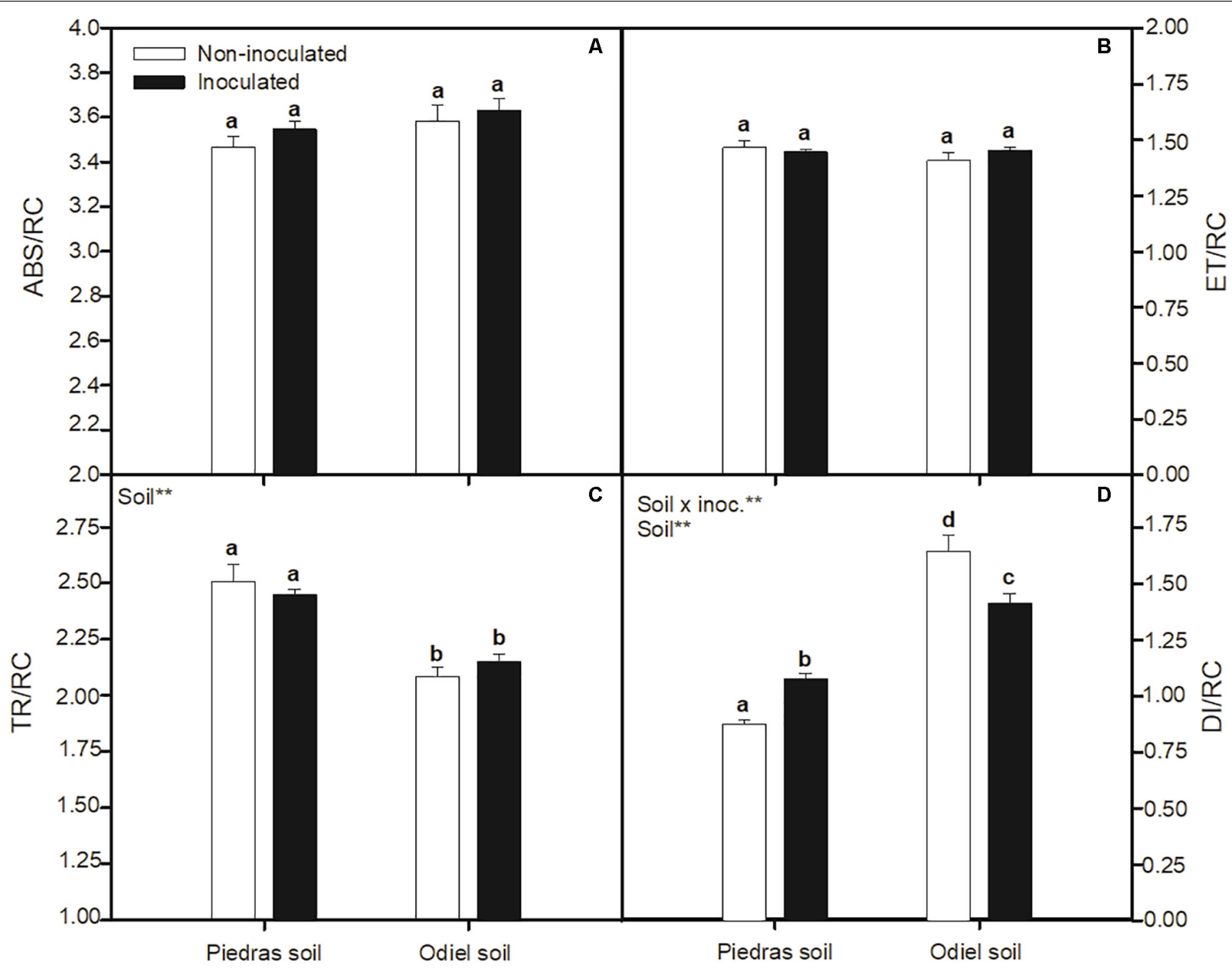

FIGURE 4 | Effect of soil bioaugmentation on S. ramosissima (A) ABS/RC, (B) ET/RC, (C) TR/RC, and (D) DI/RC after 30 days of treatment. Values are means \pm S.E. $(n=10)$. "Inoc" or "Soil" in the upper left corner of the panel indicates main or interaction significant effect $\left(^{* \star} p<0.01\right)$. Different letters indicate means that are significantly different from each other $(p<0.05)$.

TABLE 4 | Total calcium (Ca), potassium (K), magnesium (Mg), manganese (Mn), sodium (Na), and phosphorous (P) concentrations for Salicornia ramosissima tillers and roots after 30 days of bioaugmentation treatment in non-polluted Piedras and polluted Odiel sediments.

\begin{tabular}{|c|c|c|c|c|c|c|}
\hline Soil, tissue and treatment & $\mathrm{Ca}\left(\mathrm{mg} \mathrm{g}^{-1}\right)$ & $K\left(\mathrm{mg} \mathrm{g}^{-1}\right)$ & $M g\left(m g g^{-1}\right)$ & $\operatorname{Mn}\left(\mathrm{mg} \mathrm{Kg}^{-1}\right)$ & $\mathrm{Na}\left(\mathrm{mg} \mathrm{g}^{-1}\right)$ & $P\left(\mathrm{mg} \mathrm{g}^{-1}\right)$ \\
\hline \multicolumn{7}{|l|}{ Piedras } \\
\hline \multicolumn{7}{|l|}{ Leaf } \\
\hline Control & $0.34 \pm 0.01^{a}$ & $1.42 \pm 0.06^{a}$ & $0.53 \pm 0.01^{a}$ & $141.16 \pm 4.55^{a}$ & $11.03 \pm 0.44^{a}$ & $0.23 \pm 0.02^{a}$ \\
\hline Inoculated & $0.43 \pm 0.01^{b}$ & $1.45 \pm 0.07^{a}$ & $0.64 \pm 0.01^{b}$ & $174.80 \pm 3.56^{b}$ & $13.18 \pm 0.45^{b}$ & $0.24 \pm 0.01^{a}$ \\
\hline \multicolumn{7}{|l|}{ Root } \\
\hline Control & $0.26 \pm 0.02^{a}$ & $1.19 \pm 0.08^{a}$ & $0.38 \pm 0.02^{a}$ & $267.76 \pm 1.27^{a}$ & $1.57 \pm 0.09^{a}$ & $0.08 \pm 0.00^{a}$ \\
\hline Inoculated & $0.24 \pm 0.01^{a}$ & $1.21 \pm 0.05^{a}$ & $0.40 \pm 0.02^{a}$ & $258.69 \pm 4.91^{a}$ & $1.52 \pm 0.06^{a}$ & $0.07 \pm 0.00^{a}$ \\
\hline \multicolumn{7}{|l|}{ Odiel } \\
\hline \multicolumn{7}{|l|}{ Leaf } \\
\hline Control & $0.31 \pm 0.04^{a}$ & $1.28 \pm 0.16^{a}$ & $0.39 \pm 0.05^{a}$ & $67.57 \pm 7.81^{a}$ & $9.35 \pm 0.37^{a}$ & $0.25 \pm 0.03^{a}$ \\
\hline Inoculated & $0.38 \pm 0.03^{a}$ & $1.28 \pm 0.10^{a}$ & $0.45 \pm 0.04^{a}$ & $71.28 \pm 3.89^{a}$ & $11.44 \pm 0.46^{b}$ & $0.27 \pm 0.01^{a}$ \\
\hline \multicolumn{7}{|l|}{ Root } \\
\hline Control & $0.40 \pm 0.04^{a}$ & $1.41 \pm 0.01^{a}$ & $0.32 \pm 0.01^{a}$ & $349.97 \pm 13.82^{a}$ & $1.26 \pm 0.06^{a}$ & $0.21 \pm 0.01^{a}$ \\
\hline Inoculated & $0.34 \pm 0.03^{a}$ & $1.34 \pm 0.05^{a}$ & $0.31 \pm 0.01^{a}$ & $292.09 \pm 5.06^{b}$ & $1.16 \pm 0.02^{a}$ & $0.19 \pm 0.00^{a}$ \\
\hline
\end{tabular}

Values are means \pm SE. $n=3$ and different letters indicate means that are significantly different from each other ( $p<0.05$ ). 
TABLE 5 | Metal(loid) concentrations in $\mathrm{mg} \mathrm{Kg}^{-1}$ found in S. ramosissima leaves and roots growing in non-polluted Piedras sediments after 30 days of experiment.

\begin{tabular}{|c|c|c|c|c|c|c|c|}
\hline Tissue & Treatment & As & Cd & $\mathrm{Cu}$ & $\mathrm{Ni}$ & $\mathrm{Pb}$ & $\mathrm{Zn}$ \\
\hline \multirow[t]{2}{*}{ Leaves } & Non-inoculated & $0.44 \pm 0.17^{a}$ & $<0.01 \pm 0.00^{a}$ & $8.08 \pm 0.59^{a}$ & $0.43 \pm 0.12^{a}$ & $0.73 \pm 0.16^{a}$ & $18.56 \pm 1.05^{a}$ \\
\hline & Inoculated & $0.47 \pm 0.13^{a}$ & $<0.01 \pm 0.00^{\mathrm{a}}$ & $9.46 \pm 0.19^{a}$ & $1.07 \pm 0.29^{b}$ & $0.99 \pm 0.28^{a}$ & $26.30 \pm 0.80^{b}$ \\
\hline \multirow[t]{2}{*}{ Root } & Non-inoculated & $8.21 \pm 0.48^{a}$ & $0.13 \pm 0.10^{\mathrm{a}}$ & $29.60 \pm 1.07^{a}$ & $26.23 \pm 2.27^{a}$ & $17.68 \pm 1.01^{a}$ & $102.20 \pm 3.98^{a}$ \\
\hline & Inoculated & $10.73 \pm 0.53^{a}$ & $0.23 \pm 0.11^{a}$ & $34.38 \pm 1.01^{\mathrm{b}}$ & $33.44 \pm 0.93^{b}$ & $21.72 \pm 0.79^{b}$ & $99.47 \pm 1.53^{a}$ \\
\hline
\end{tabular}

Values are means \pm S.E. Different letters indicate statistical differences for each metal(loid) and tissue between bioaugmentation treatments.

TABLE 6 | Distribution of arsenic (As), cadmium (Cd), copper (Cu), nickel (Ni), lead (Pb), and zinc (Zn) in estuarine soils of our study and S. ramosissima in natural conditions (non-inoculated).

\begin{tabular}{|c|c|c|c|c|c|c|}
\hline Odiel vs. Piedras & As & Cd & $\mathrm{Cu}$ & $\mathbf{N i}$ & $\mathrm{Pb}$ & $\mathrm{Zn}$ \\
\hline Soil & 60 & 10 & 29 & 1 & 36 & 7 \\
\hline S. ramosissima roots & 31 & 4 & 14 & 1 & 17 & 3 \\
\hline S. ramosissima leaves & 18 & 1 & 2 & 1 & 14 & 2 \\
\hline
\end{tabular}

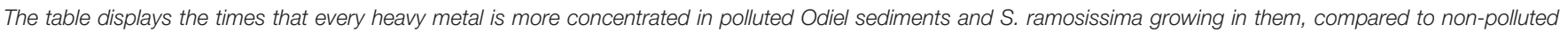

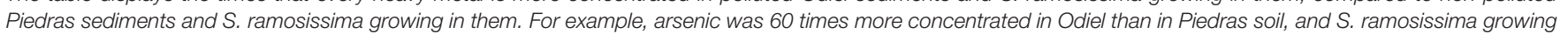
in Odiel soil accumulated 31 times more arsenic in roots and 18 in leaves than S. ramosissima growing in Piedras soil.

(300 $\left.\mathrm{mg} \mathrm{Kg}^{-1}\right)$, and $\mathrm{Zn}\left(300 \mathrm{mg} \mathrm{Kg}^{-1}\right)$ recorded in roots of plants growing in polluted sediments (with approximately As $800 \mathrm{mg} \mathrm{Kg}^{-1}$, Cd $2 \mathrm{mg} \mathrm{Kg}^{-1}$, Cu $1000 \mathrm{mg} \mathrm{Kg}^{-1}, \mathrm{Ni}$ $30 \mathrm{mg} \mathrm{Kg}^{-1}, \mathrm{~Pb} 1000 \mathrm{mg} \mathrm{Kg}^{-1}$, and $\mathrm{Zn} 800 \mathrm{mg} \mathrm{Kg}^{-1}$ ). Moreover, it is important to note that accumulation takes place mainly at root level. More specifically, root concentration of the analyzed metals in $S$. ramosissima growing in polluted Odiel sediments was approximately 20, 50, 20, 25, 30, and 15 times, respectively, higher than in leaves. Other authors also observed Cd accumulation capacity in this species (Pedro et al., 2013; Pérez-Romero et al., 2016). In the same line, As, Cd, $\mathrm{Li}, \mathrm{Ni}$, and $\mathrm{Pb}$ tolerance and accumulation have been noted by several authors for other Salicornia species, like Salicornia brachiata, S. europaea, and Salicornia iranica (Ozawa et al., 2010; Sharma et al., 2010; Kaviani et al., 2017a,b; Lou et al., 2020). Toxic metals are thought to enter root cells by means of the same uptake processes that move essential micronutrient metal ions, as for example competitive transport of $\mathrm{Cd}$ via voltagegated cation channels. Also, these species seem to use different mechanisms for restricting the transport of toxic elements within the plant, including sub-cellular compartmentalization of the metal, namely in vacuoles, and the sequestration of the metal by specially produced organic compounds, like phytochelatins, concentrating metal in the plants roots (Pedro et al., 2013). Low metal translocation rates does not mean lower phytoremediation capacity, but different phytoremediation strategies. Thus, S. ramosissima may be appropriate for phytostabilization purposes, nor for phytoextraction. Bacteria inoculation with the selected consortium incremented heavy metal phytoaccumulation in S. ramosissima. However, we observed that this effect was not due to an amelioration of $S$. ramosissima accumulation ability, but to an increment in plant biomass, which permits a greater accumulation of heavy metals. This effect was also observed by Mesa et al. (2015a) after bioaugmentation with PGP endophytic bacteria in S. maritima growing in polluted Tinto salt marsh sediments. Nevertheless, other studies concluded that bioaugmentation with
PGP rhizobacteria in halophytes A. macrostachyum, Suaeda vera and hyperaccumulators $S$. maritima and $S$. densiflora incremented significantly root metal phytoaccumulation ability (Mateos-Naranjo et al., 2015; Mesa et al., 2015b; Navarro-Torre et al., 2017a; Gómez-Garrido et al., 2018). Bacteria used in this work may increase plant tolerance through different mechanisms. For example, higher ETR values recorded in inoculated plants may suggest that several defense mechanisms could be activated, like the dissipation of energy excess as photorespiration or heat (Duarte et al., 2013), helping plants to reduce physiological stress when they are exposed to heavy metals. However, most of the energy absorbed would not take the photochemical pathway (Flexas et al., 2012). This fact affects photosynthetic productivity and, therefore, growth in plants not inoculated, which would support our experimental growth results. Also, PGPB may induce plant enzymatic antioxidant defense, as has been demonstrated by several authors (Kong et al., 2015; Mesa-Marín et al., 2018). Besides, PGPB may confer metal resistance by chemical detoxification, accumulation, transformation and sequestration of heavy metals, altering their phytoavailability in contaminated soils and thus diminishing the metal phytotoxicity (Kong and Glick, 2017). Moreover, numerous studies have suggested that inoculation of plants with PGPB that produce ACC deaminase and IAA, as is currently the case, may play an important role in improving metal phytoremediation by increasing heavy metal tolerance. However, most of these studies did not provide definitive and mechanistic proof of the direct involvement of these compounds (Kong and Glick, 2017). Indeed, there is a wide lack of knowledge regarding to specific mechanism underlying these effects, that opens a broad area of research.

A fact that is important to be noted is that PGPB bioaugmentation with this consortium did not promote in $S$. ramosissima higher accumulation rates of heavy metals in leaves, nor translocation from roots to leaves. This is relevant because $S$. ramosissima may be used as leafy vegetable (Ventura and Sagi, 2013; Ventura et al., 2015; Patel, 2016; Barreira et al., 2017) and it is may be considered a cash-crop halophyte 


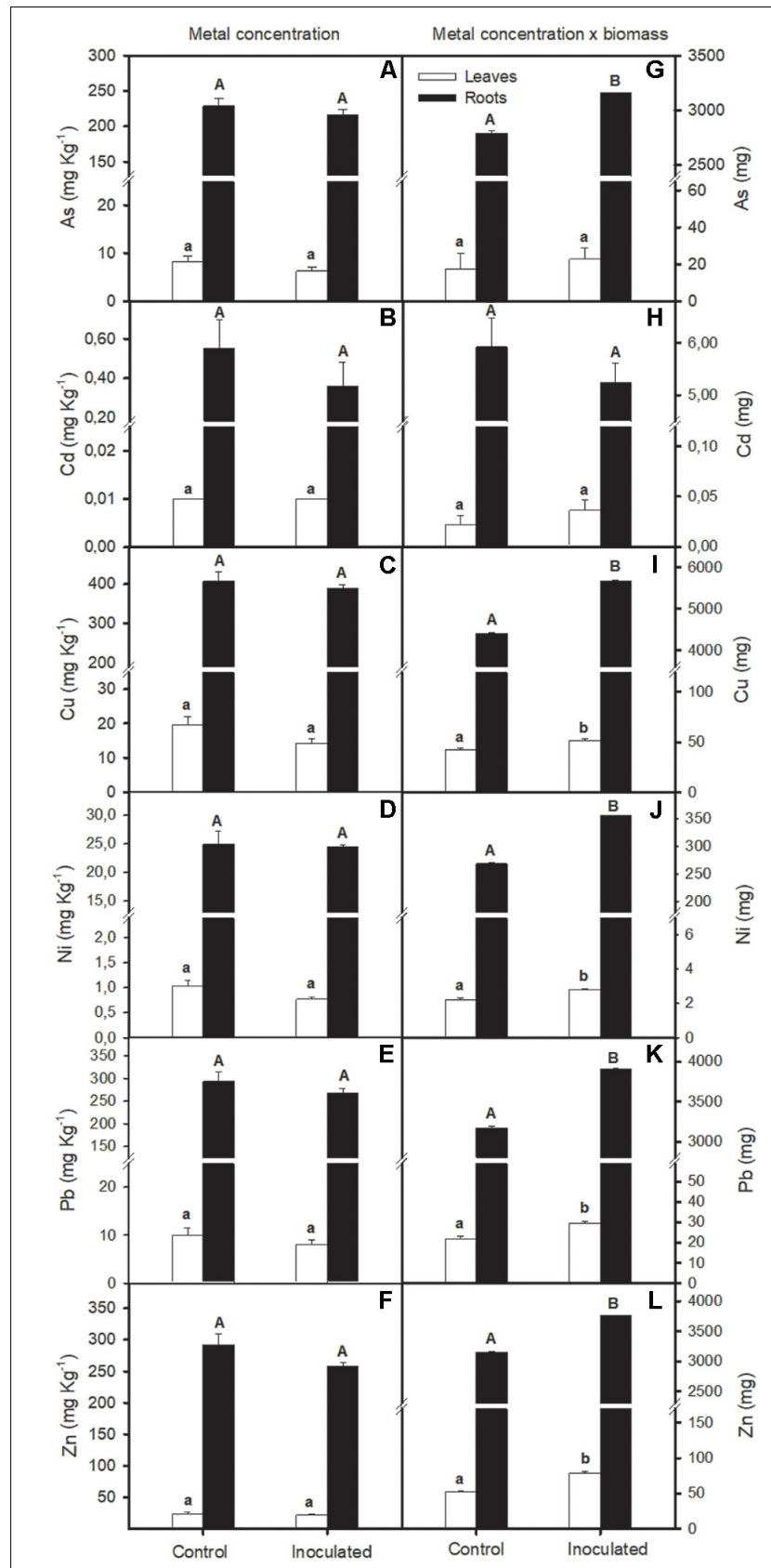

FIGURE 5 | Effect of soil bioaugmentation in polluted Odiel sediments on S. ramosissima heavy metal accumulation after 30 days of treatment initiation. In the left column, total (A) arsenic, As, (B) cadmium, Cd, (C) copper, Cu, (D) nickel, $\mathrm{Ni}$, (E) lead, $\mathrm{Pb}$, and (F) zinc, Zn, for leaves and roots of S. ramosissima. In the right column, total concentration values have been normalized for $S$. ramosissima biomass after 30 days of treatment (G-L) Values are means \pm S.E. $(n=3)$. Different capital letters indicate statistical differences between inoculation treatments in roots and different lower case letters in leaves $(p<0.05)$.

in scenarios of climate change (Mesa-Marín et al., 2019c). In several studies, bacteria promoted metal translocation from roots to shoots, mainly through chemical transformation of metals that increment their bioavailability (reviewed in Kong and Glick, 2017). In this case, bacteria did not promote metal translocation to leaves. Lastly, a remarkable result was also that bioaugmentation increased $\mathrm{Na}$ concentration in leaves, as observed by other authors for the halophyte A. macrostachyum (Navarro-Torre et al., 2017a,b). This may be connected plant osmoregulation by salt uptake, as suggested previously by Redondo-Gómez et al. (2010).

As an approach for practical purpose, it would be interesting to study the effect of PGPB bioaugmentation over time. Important considerations are the survival and colonization potential of the inoculated strains, as well as the potential ecological risks of introducing non-native plant and microbial species into field sites. In this sense, it should be highlighted that rhizobacteria used as an inoculum in this experiment were previously isolated from S. ramosissima rhizosphere in SW Spain salt marshes. The rationale behind inoculation with native microorganisms isolated from the sampling site and plant is that a bacterial strain from a population that is spatially and temporally prevalent in a concrete habitat, has more chances to persist when reintroduced by inoculation, than others being alien or transient to such habitat, especially in polluted conditions like Odiel salt marsh (Vogel, 1996). Non-native inoculants may have poor survival and colonization ability, and therefore they may be not sufficient to effectively support phytoremediation over time. In a long period, it could be expected that inoculated bacteria successfully colonize the rhizosphere and effectively facilitate plant metal uptake over time (Ma et al., 2015), and even the microbial community diversity in the rhizosphere may decrease (Liu et al., 2015).

In conclusion, our data suggested that inoculation with heavy metal resistant PGPB improved S. ramosissima plant growth, photosynthetic fitness, intrinsic water use efficiency and water content in polluted sediments. Also, we observed that S. ramosissima was able to accumulate great concentrations of heavy metals, mostly at root level, and that bioaugmentation incremented $S$. ramosissima heavy metal phytoremediation potential due to plant biomass increment achieved after inoculation, which enabled a greater accumulation capacity. Thus, our results claim the potential of using inoculation with heavy metal resistant PGPB to strengthen the capacity of S. ramosissima as candidate species in phytoremediation of salty degraded ecosystems.

\section{DATA AVAILABILITY STATEMENT}

The original contributions presented in the study are included in the article/supplementary material, further inquiries can be directed to the corresponding author.

\section{AUTHOR CONTRIBUTIONS}

JM-M: conceptualization, methodology, formal analysis, writing - original draft, and writing reviewing and editing. JP-R: methodology, formal analysis, and writing - reviewing and editing. SR-G: resources, funding acquisition, and writing - reviewing 
and editing. IR-L and EP: resources and writing - reviewing and editing. EM-N: methodology, formal analysis, resources, supervision, funding acquisition, and writing - reviewing and editing. All authors contributed to the article and approved the submitted version.

\section{FUNDING}

This work has been supported by the Ministerio de Economía y Competitividad (CGL2016-75550-R, AEI/FEDER, UE). JM-M

\section{REFERENCES}

Anjum, N. A., Ahmad, I., Válega, M., Mohmood, I., Gill, S. S., Tuteja, N., et al. (2014). Salt marsh halophyte services to metal-metalloid remediation: assessment of the processes and underlying mechanisms. Crit. Rev. Environ. Sci. Technol. 44, 2038-2106. doi: 10.1080/10643389.2013.828271

Backer, R., Rokem, J. S., Ilangumaran, G., Lamont, J., Praslickova, D., Ricci, E., et al. (2018). Plant growth-promoting Rhizobacteria: context, mechanisms of action, and roadmap to commercialization of biostimulants for sustainable agriculture. Front. Plant Sci. 9:1473. doi: 10.3389/fpls.2018.01473

Barreira, L., Resek, E., Rodrigues, M. J., Rocha, M. I., Pereira, H., Bandarra, N., et al. (2017). Halophytes: gourmet food with nutritional health benefits? J. Food Compos. Anal. 59, 35-42. doi: 10.1016/j.jfca.2017.02.003

Bogino, P. C., Oliva, M., de las, M., Sorroche, F. G., and Giordano, W. (2013). The role of bacterial biofilms and surface components in plant-bacterial associations. Int. J. Mol. Sci 14, 15838-15859. doi: 10.3390/ijms140815838

Davy, A. J., Bishop, G. F., and Costa, C. S. B. (2001). Salicornia L. (Salicornia pusilla J. Woods, S. ramosissima J. Woods, S. europaea L., S. obscura P.W. Ball \& Tutin and S. dolichostacya Moss). J. Ecol. 89, 681-707. doi: 10.1046/j.0022-0477.2001. 00607.x

de Andalucía, J. (1999). Los Criterios y Estándares Para Declarar un Suelo Contaminado en Andalucía y la Metodología y Técnicas de Toma de Muestra y Análisis Para su Investigación. Available online at: http://www.juntadeandalucia.es/medioambiente/site/ portalweb/menuitem.7e1cf46ddf59bb227a9ebe205510e1ca?vgnextoid= $47 \mathrm{dbbb} 45 \mathrm{c} 8 \mathrm{bab} 010 \mathrm{VgnVCM} 1000000624 \mathrm{e} 50 \mathrm{aRCRD} \&$ vgnextchannel= 2896a7aaaf4f4310VgnVCM2000000624e50aRCRD (accessed March 2020).

de Souza, R., Ambrosini, A., and Passaglia, L. M. P. (2015). Plant growth-promoting bacteria as inoculants in agricultural soils. Genet. Mol. Biol. 38, 401-419. doi: 10.1590/S1415-475738420150053

Duarte, B., Santos, D., Marques, J. C., and Caçador, I. (2013). Ecophysiological adaptations of two halophytes to salt stress: photosynthesis, PS II photochemistry and anti-oxidant feedback - Implications for resilience in climate change. Plant Physiol. Biochem. 67, 178-188. doi: 10.1016/j.plaphy.2013.03.004

Duca, D., Lorv, J., Patten, C. L., Rose, D., and Glick, B. R. (2014). Indole-3-acetic acid in plant-microbe interactions. Antonie Van Leeuwenhoek 106, 85-125. doi: 10.1007/s10482-013-0095-y

Flexas, J., Loreto, F., and Medrano, H. (2012). Terrestrial Photosynthesis in A Changing Environment. A Molecular, Physiological and Ecological Approach. Cambridge: Cambridge University Press. doi: 10.1017/CBO9781139051477

Flowers, T. J., and Colmer, T. D. (2008). Salinity tolerance in halophytes. New Phytol. 179, 945-963. doi: 10.1111/j.1469-8137.2008.02531.x

Glick, B. R. (2012). Plant growth-promoting bacteria?: mechanisms and pplications. Scientifica 2012:963401. doi: 10.6064/2012/963401

Glick, B. R. (2014). Bacteria with ACC deaminase can promote plant growth and help to feed the world. Microbiol. Res. 169, 30-39. doi: 10.1016/j.micres.2013. 09.009

Gómez-Garrido, M., Mora Navarro, J., Murcia Navarro, F. J., and Faz Cano, Á (2018). The chelating effect of citric acid, oxalic acid, amino acids and Pseudomonas fluorescens bacteria on phytoremediation of $\mathrm{Cu}, \mathrm{Zn}$, and $\mathrm{Cr}$ from soil using Suaeda vera. Int. J. Phytoremed. 20, 1033-1042. doi: 10.1080/ 15226514.2018.1452189 is grateful for personal funding to Ministerio de Ciencia, Innovación y Universidades, Spain, (Juan de la Cierva Formación Ref. FJC2018-036625-I).

\section{ACKNOWLEDGMENTS}

We thank the University of Seville Greenhouse General Services (CITIUS), Miguel Bernabeu Meana and Francisco Ruano García for their collaboration and technical support.

Hoagland, D. R., and Arnon, D. I. (1938). The water-culture method for growing plants without soil. Calif. Agric. Exp. Stn. Bull. 347, 1-39.

Kaviani, E., Niazi, A., Heydarian, Z., Moghadam, A., Ghasemi-Fasaei, R., and Abdollahzadeh, T. (2017a). Phytoremediation of Pb-Contaminated soil by Salicornia iranica: key physiological and molecular mechanisms involved in $\mathrm{Pb}$ detoxification. Clean Soil Air Water 45:1500964. doi: 10.1002/clen.201500964

Kaviani, E., Niazi, A., Moghadam, A., Taherishirazi, M., and Heydarian, Z. (2017b). Phytoremediation of Ni-contaminated soil by Salicornia iranica. Environ. Technol. 40, 270-281. doi: 10.1080/09593330.2017.1387179

Kong, Z., and Glick, B. R. (2017). The role of plant growth-promoting bacteria in metal phytoremediation. Adv. Microbial Physiol. 71, 97-132. doi: 10.1016/bs. ampbs.2017.04.001

Kong, Z., Mohamad, O. A., Deng, Z., Liu, X., Glick, B. R., and Wei, G. (2015). Rhizobial symbiosis effect on the growth, metal uptake, and antioxidant responses of Medicago lupulina under copper stress. Environ. Sci. Pollut. Res. 22, 12479-12489. doi: 10.1007/s11356-015-4530-7

Liang, L., Liu, W., Sun, Y., Huo, X., Li, S., and Zhou, Q. (2017). Phytoremediation of heavy metal-contaminated saline soils using halophytes: current progress and future perspectives. Environ. Rev. 25, 269-281. doi: 10.1139/er-2016-0063

Liu, W., Wang, Q., Wang, B., Hou, J., Luo, Y., Tang, C., et al. (2015). Plant growth-promoting rhizobacteria enhance the growth and Cd uptake of Sedum plumbizincicola in a Cd-contaminated soil. J. Soils Sediments 15, 1191-1199. doi: 10.1007/s11368-015-1067-9

Lou, T., Lü, S., and Li, Y. (2020). Application potential of Salicornia europaea in remediation of $\mathrm{Cd}, \mathrm{Pb}$ and $\mathrm{Li}$ contaminated saline soil. Sheng Wu Gong Cheng Xue Bao 36, 481-492. doi: 10.13345/j.cjb.190377

Ma, Y., Oliveira, R. S., Nai, F., Rajkumar, M., Luo, Y., Rocha, I., et al. (2015). The hyperaccumulator Sedum plumbizincicola harbors metal-resistant endophytic bacteria that improve its phytoextraction capacity in multi-metal contaminated soil. J. Environ. Manage. 156, 62-69. doi: 10.1016/j.jenvman.2015.03.024

Manousaki, E., and Kalogerakis, N. (2011). Halophytes present new opportunities in phytoremediation of heavy metals and saline soils. Ind. Eng. Chem. Res. 50, 656-660. doi: 10.1021/ie100270x

Mateos-Naranjo, E., Mesa, J., Pajuelo, E., Perez-Martin, A., Caviedes, M. A., and Rodríguez-Llorente, I. D. (2015). Deciphering the role of plant growthpromoting rhizobacteria in the tolerance of the invasive cordgrass Spartina densiflora to physicochemical properties of salt-marsh soils. Plant Soil 394, 45-55. doi: 10.1007/s11104-015-2504-7

Mateos-Naranjo, E., Redondo-Gómez, S., Cambrollé, J., Luque, T., and Figueroa, M. E. (2008). Growth and photosynthetic responses to copper stress of an invasive cordgrass, Spartina densiflora. Plant Biol. 10, 754-762. doi: 10.1111/ j.1438-8677.2008.00098.x

Mesa, J., Mateos-Naranjo, E., Caviedes, M. A., Redondo-Gómez, S., Pajuelo, E., and Rodríguez-Llorente, I. D. (2015a). Endophytic cultivable bacteria of the metal bioaccumulator Spartina maritima improve plant growth but not metal uptake in polluted marshes soils. Front. Microbiol. 6:1450. doi: 10.3389/fmicb. 2015.01450

Mesa, J., Mateos-Naranjo, E., Pajuelo, E., Caviedes, M. A., and Rodríguez-Llorente, I. D. (2016). Heavy metal pollution structures soil bacterial community dynamics in SW spain polluted salt marshes. Water Air Soil Pollut. 227:466.

Mesa, J., Rodríguez-Llorente, I. D., Pajuelo, E., Piedras, J. M. B., Caviedes, M. A., Redondo-Gómez, S., et al. (2015b). Moving closer towards restoration of contaminated estuaries: Bioaugmentation with autochthonous rhizobacteria 
improves metal rhizoaccumulation in native Spartina maritima. J. Hazard. Mater. 300, 263-271. doi: 10.1016/j.jhazmat.2015.07.006

Mesa-Marín, J., Barcia-Piedras, J. M., Mateos-Naranjo, E., Cox, L., Real, M., PérezRomero, J. A., et al. (2019a). Soil phenanthrene phytoremediation capacity in bacteria-assisted Spartina densiflora. Ecotoxicol. Environ. Saf. 182:109382. doi: 10.1016/j.ecoenv.2019.109382

Mesa-Marín, J., Del-Saz, N. F., Rodríguez-Llorente, I. D., Redondo-Gómez, S., Pajuelo, E., Ribas-Carbó, M., et al. (2018). PGPR reduce root respiration and oxidative stress enhancing Spartina maritima root growth and heavy metal Rhizoaccumulation. Front. Plant Sci. 9:1500. doi: 10.3389/fpls.2018. 01500

Mesa-Marín, J., Mateos-Naranjo, E., Rodríguez-Llorente, I. D., Pajuelo, E., and Redondo-Gómez, S. (2019b). "Synergic effects of rhizobacteria: increasing use of halophytes in a changing world," in Halophytes and Climate Change: Adaptive Mechanisms and Potential Uses, eds M. Hasanuzzaman, S. Shabala, and M. Fujita (Boston, MA: CABI), 240-254. doi: 10.1079/9781786394330.0240

Mesa-Marín, J., Pérez-Romero, J. A., Mateos-Naranjo, E., Bernabeu-Meana, M., Pajuelo, E., Rodríguez-Llorente, I. D., et al. (2019c). Effect of plant growth-promoting Rhizobacteria on Salicornia ramosissima seed germination under salinity, CO2 and temperature stress. Agronomy 9:655. doi: 10.3390/ agronomy9100655

Navarro-Torre, S., Barcia-Piedras, J. M., Caviedes, M. A., Pajuelo, E., RedondoGómez, S., Rodríguez-Llorente, I. D., et al. (2017a). Bioaugmentation with bacteria selected from the microbiome enhances Arthrocnemum macrostachyum metal accumulation and tolerance. Mar. Pollut. Bull. 117, 340-347. doi: 10.1016/j.marpolbul.2017.02.008

Navarro-Torre, S., Barcia-Piedras, J. M., Mateos-Naranjo, E., Redondo-Gómez, S., Camacho, M., Caviedes, M. A., et al. (2017b). Assessing the role of endophytic bacteria in the halophyte Arthrocnemum macrostachyum salt tolerance. Plant Biol. 19, 249-256. doi: 10.1111/plb.12521

Neilands, J. B. (1995). Siderophores: structure and function of microbial iron transport compounds. J. Biol. Chem. 270, 26723-26726. doi: 10.1074/jbc.270. 45.26723

Ozawa, T., Miura, M., Fukuda, M., and Kakuta, S. (2010). Cadmium tolerance and accumulation in a halophyte Salicornia europaea as a new candidate for phytoremediation of saline soils. Sci. Rep. Grad. Sch. Life Environ. Sci. 60, 1-8. doi: $10.24729 / 00000693$

Pan, X., Yang, J., Zhang, D., and Mu, S. (2012). Lead complexation behaviour of root exudates of salt marsh plant Salicornia europaea L. Chem. Speciat. Bioavailab. 24, 60-63. doi: 10.3184/095422912X13257863158575

Paredes-Páliz, K. I., Mateos-Naranjo, E., Doukkali, B., Caviedes, M. A., RedondoGómez, S., Rodríguez-Llorente, I. D., et al. (2017). Modulation of Spartina densiflora plant growth and metal accumulation upon selective inoculation treatments: a comparison of gram negative and gram positive rhizobacteria. Mar. Pollut. Bull. 125, 77-85. doi: 10.1016/j.marpolbul.2017.07.072

Patel, S. (2016). Salicornia: evaluating the halophytic extremophile as a food and a pharmaceutical candidate. 3 Biotech 6:104.

Pedro, C. A., Santos, M. S. S., Ferreira, S. M. F., and Gonçalves, S. C. (2013). The influence of cadmium contamination and salinity on the survival, growth and phytoremediation capacity of the saltmarsh plant Salicornia ramosissima. Mar. Environ. Res. 92, 197-205. doi: 10.1016/j.marenvres.2013.09.018

Pérez-Romero, J. A., Redondo-Gómez, S., and Mateos-Naranjo, E. (2016). Growth and photosynthetic limitation analysis of the Cd-accumulator Salicornia ramosissima under excessive cadmium concentrations and optimum salinity conditions. Plant Physiol. Biochem. 109, 103-113. doi: 10.1016/j.plaphy.2016. 09.011

Redondo-Gómez, S. (2013). Bioaccumulation of heavy metals in Spartina. Funct. Plant Biol. 40:913. doi: 10.1071/FP12271

Redondo-Gómez, S., Naranjo, E., Figueroa, E., and Davy, A. (2010). Salt stimulation of growth and photosynthesis in an extreme halophyte, Arthrocnemum macrostachyum. Plant Biol. 12, 79-87. doi: 10.1111/j.1438-8677. 2009.00207.x

Sharma, A., Gontia, I., Agarwal, P. K., and Jha, B. (2010). Accumulation of heavy metals and its biochemical responses in Salicornia brachiata, an extreme halophyte. Mar. Biol. Res. 6, 511-518. doi: 10.1080/174510009034 34064

Shrestha, B., Lipe, S., Johnson, K. A., Zhang, T. Q., Retzlaff, W., and Lin, Z. Q. (2006). Soil hydraulic manipulation and organic amendment for the enhancement of selenium volatilization in a soil-pickleweed system. Plant Soil 288, 189-196. doi: 10.1007/s11104-006-9107-2

Strasser, R. J., Tsimilli-Michael, M., and Srivastava, A. (2004). "Analysis of the Chlorophyll a Fluorescence Transient," in Chlorophyll a Fluorescence: A Signature of Photosynthesis, eds G. C. Papageorgiou and Govindjee (Dordrecht: Springer), 321-362. doi: 10.1007/978-1-4020-3218-9_12

Tardieu, F. (2012). Any trait or trait-related allele can confer drought tolerance: just design the right drought scenario. J. Exp. Bot. 63, 25-31. doi: 10.1093/jxb/ err269

Usman, K., Al-Ghouti, M. A., and Abu-Dieyeh, M. H. (2018). "Phytoremediation: Halophytes as promising heavy metal hyperaccumulators," in Heavy Metals, eds S. Hosam and M. El-Din (London: IntechOpen), 201-217. doi: 10.5772/ intechopen.73879

Van Oosten, M. J., and Maggio, A. (2015). Functional biology of halophytes in the phytoremediation of heavy metal contaminated soils. Environ. Exp. Bot. 111, 135-146. doi: 10.1016/j.envexpbot.2014.11.010

Ventura, Y., Eshel, A., Pasternak, D., and Sagi, M. (2015). The development of halophyte-based agriculture: past and present. Ann. Bot. 115, 529-540. doi: 10.1093/aob/mcu173

Ventura, Y., and Sagi, M. (2013). Halophyte crop cultivation: the case for Salicornia and Sarcocornia. Environ. Exp. Bot. 92, 144-153. doi: 10.1016/j.envexpbot.2012. 07.010

Vogel, T. M. (1996). Bioaugmentation as a soil bioremediation approach. Curr. Opin. Biotechnol. 7, 311-316. doi: 10.1016/S0958-1669(96) 80036-X

Wang, H. L., Tian, C. Y., Jiang, L., and Wang, L. (2014). Remediation of heavy metals contaminated saline soils: a halophyte choice? Environ. Sci. Technol. 48, 21-22. doi: 10.1021/es405052j

Conflict of Interest: The authors declare that the research was conducted in the absence of any commercial or financial relationships that could be construed as a potential conflict of interest.

Copyright (C) 2020 Mesa-Marín, Pérez-Romero, Redondo-Gómez, Pajuelo, Rodríguez-Llorente and Mateos-Naranjo. This is an open-access article distributed under the terms of the Creative Commons Attribution License (CC BY). The use, distribution or reproduction in other forums is permitted, provided the original author(s) and the copyright owner(s) are credited and that the original publication in this journal is cited, in accordance with accepted academic practice. No use, distribution or reproduction is permitted which does not comply with these terms. 